22. Tufanov, A. (2012). To the zaum. Background music and the functions of consonant phonemes. With the portrait. Work thin. I. Nefedova. (facsimile edition). B. m.: Salamandra [in Russian].

23. Fateeva, N. A. (2012). Neologisms-terms as elements of individual «poetic philology»: the possibility of a vocabulary presentation. Proceedings of the RAS. A series of literature and language, V. 71, № 5, 46-56 [in Russian].

24. Freud, Z. (2007). Introduction to psychoanalysis: Lectures 1-15. SPb.: Publishing House «AlphabetClassic» [in Russian].

Russian].

25. Khlebnikov, V. (2005). Collected Works: In 6 volumes. Moscow: IMLI RAS, Volume 6, Book. 1 [in

26. Khlebnikov, V., Kruchenykh, A., Guro, E. (1913). Three. SPb.: Crane [in Russian].

27. Shershenevich, V. (1913). Futurism without a mask. Compilation introduction. M.: Type. Ac About Pec. and publ. affairs «Moskovsk. Izdat.» [in Russian].

28. Shklovsky, V. B. (1990). The Hamburg Account: Articles - Memories - Essay (1914-1933). M.: Soviet writer [in Russian]. Russian].

29. Engelhardt, B. M. (1927). The formal method in the history of literature. Leningrad: AKADEMIA [in

30. Yakushin, B. V. (1984). Hypotheses about the origin of the language. M.: Science [in Russian].

Стаття надійшла до редакизї 30.11 .2018 p.

УДК $393.92(477.85)$

\author{
Козек Микола Іванович, \\ аспірант Київського національного \\ університету культури і мистецтв \\ ORCID 0000-0002-6119-561X \\ KozekMykola1@gmail.com
}

\title{
РЕГІОНАЛЬНІ ОСОБЛИВОСТІ ПОХОВАЛЬНОЇ ОБРЯДОВОСТІ НА БУКОВИНСЬКІЙ ГУЦУЛЬЩИНІ
}

\begin{abstract}
Метою дослідження $є$ виявлення та обгрунтування регіональних особливостей в поховальній обрядовості українців Буковинської Гуцульщини. Методологія дослідження полягає в застосуванні аналітичного, історичного, порівняльного методів, та грунтується на зборі інформації 3 респондентів Буковинської Гуцульщини. Наукова новизна. Виявлено нові риси в поховальній обрядовості притаманні українцям Буковинської Гуцульщини. Висновки. Досліджено, що в поховальній обрядовості на Буковинській Гуцульщині є усталена послідовність дій, яка передається з покоління в покоління. Гуцули вірять, що від належного дотримання та виконання предкових поховальних обрядових дій залежить добробут всієї родини, їх господарства. Не менше значення, ніж дотримання поховальних дій, мають обрядові дії, пов'язані із вшануванням культу предків, які мають велику духовну цінність для українців Буковини. Гуцули вірять, що їх померлі родичі впливають на перебіг подій в родині, вони можуть як допомагати своїм рідним, так і робити їм погані вчинки. За давнім віруванням буковинських гуцулів саме предки забирають своїх родичів на «той» світ, коли хтось з кревних помирає. Таким чином, предки на Буковинській Гуцульщині виступають посередниками між живим світом і світом мертвих.
\end{abstract}

Ключові слова: поховальні обряди, гуцули, культ предків, традиція, культура, вірування.

Козек Николай Иванович, аспирант Киевского национального университета культуры и искусств Региональные особенности погребальных обрядов на Буковинской Гуцульщине

Целью исследования является выявление и обоснование региональных особенностей в погребальной обрядности украинцев Буковинской Гуцульщины. Методология исследования заключается в применении аналитического, исторического, сравнительного методов, и основывается на сборе информации из респондентов Буковинской Гуцульщины. Научная новизна. Обнаружены новые черты в погребальной обрядности, присущие украинцам Буковинской Гуцульщины. Выводы. Доказано, что в погребальной обрядности на Буковинской Гуцульщине есть устоявшаяся последовательность действий, которая передается из поколения в поколение. Гуцулы верят, что от надлежащего соблюдения и выполнения предковых погребальных обрядовых действий зависит благосостояние всей семьи, их хозяйства. Не меньшее значение, чем соблюдение погребальных действий, имеют обрядовые действия, связанные с чествованием культа предков, которые имеют большую духовную ценность для украинцев Буковины. Гуцулы верят, что их умершие родственники влияют на ход событий в семье, они могут как помогать своим родным, так и делать им плохие поступки. По древнему верованию буковинских гуцулов, именно предки забирают своих родственников на «тот» мир, когда кто-то из

(C) Козек М. I., 2019 
кровных умирает. Таким образом, предки на Буковинской Гуцульщине выступают посредниками между живым миром и миром мертвых.

Ключевые слова: погребальные обряды, гуцулы, культ предков, традиция, культура, верования.

Kozek Mykola, postgradute student Kyiv National University of Culture and Arts

Regional peculiarities of funeral rituals in Bukovynska Hutsulshchyna

The purpose of the article is discovering and grounding of regional peculiarities in funeral rituals of Ukrainians in Bukovynska Hutsulshchyna. The methodology of the research is based on the application of analytical, historic, comparative methods, on data collection from respondents in Bukovynska Hutsulshchyna. Scientific novelty: new features of funeral rituals, peculiar for Ukrainians in Bukovynska Hutsulshchyna, are found and described. Conclusions: A fixed sequence of actions, which exists in funeral rituals in Bukovynska Hutsulshchyna and is handed over from generation to generation there is an established sequence of actions, which is passed from generation to generation, is researched. Hutsuls believe that the whole family's prosperity, their well-being depends on their proper keeping to and performing their ancestral funeral ritual actions. Not less importance is attached to rituals connected not only with keening with honoring «the ancestors cult» which possesses spiritual value for Bukovynska Ukrainians. Hutsuls believe, that their dead relatives influence the stream of events in the family; they can both help their relatives or do bad actions to them. According to old beliefs of Bukovyna Hutsuls, just «ancestors» take their relatives to «another» world, when they die. An such a way «ancestors» are mediators between two worlds - living and dead.

Key words: funeral rituals, Hutsuls, ancestors cult, tradition, culture, beliefs.

Актуальність теми дослідження. На рубежі XX - XXI ст. очевидно простежується відчутний занепад високогуманних форм традиційної поховальної обрядовості. Родовідна бездуховність, забуття своїх предків, зневажливе ставлення до своїх родинних обов'язків, негативно впливає на сучасну сімейну обрядовість. Безпам'яцтво у родовідному духовному надбанні створює непорозуміння між рідними, і виникає негативна тенденція, коли діти поміщають своїх батьків у пристарілі будинки, а молоді батьки відмовляються від дітей, віддають їх у сиротинці.

Поховальна обрядовість відіграє важливу роль в духовному житті та світогляді буковинських гуцулів. Гуцули твердо вірять, що їх кревні померлі родичі, а особливо батьки, допомагають їм у реальному житті, позитивно впливають на перебіг подій в родині, якщо рідні добре 3 ними обходяться після смерті, і погано, якщо навпаки.

Аналіз праць, у яких висвітлюються питання 3 проблематики поховальної обрядовості, структура компонентів поховальної обрядовості Буковинської Гуцульщини та Гуцульщини в цілому, були досліджені у працях таких відомих дослідників як: Г. Кожолянко, І. Сеньків, О. Воропай, О. Кожолянко, Р. Гузій, Р.Кайндль, та ін. Такі відомі науковці Гуцульщини як: Г. Кожолянко, «Духовна культура українців Буковини», М. Маєрчик, «Ритуал і тіло», О. Воропай, «Звичаї нашого народу» аналізували поховальну обрядовість буковинських гуцулів у порівнянні з розвитком інших як гірських, так і рівнинних регіонів українських народів. Дослідження науковців Гуцульщини I. Сеньків, «Гуцульська спадщина», Р. Гузій, «3 народної танатології: карпатознавчі розсліди», Р. Кайндль, «Гуцули» та Л. Мусіхіна, «Магія гір» базуються на загальних відомостях про похоронну обрядовість Гуцульщини. Інформація про поховальну обрядовість 3 конкретних сіл Буковинської Гуцульщини практично відсутня. Метою нашого дослідження $\epsilon$ виявлення та обгрунтування регіональних особливостей в поховальній обрядовості українців Буковинської Гуцульщини.

Виклад основного матеріалу. Поховальна обрядовість - це складова загальної сімейної обрядовості українців, яка ділиться на усталену кількість дій у родині небіжчика. Поховальну обрядовість на Буковинській Гуцульщині можна поділити на три етапи. Перший - підготовка людини до своєї смерті, другий - похорон, третій - вшанування культу предків.

Ще 3 язичницьких часів у традиційній поховальній обрядовості гуцулів предки опорядкували певні елементи дій, пов'язані з підготовкою до загробного життя. Зазвичай гуцули готувалися до загробного життя у поважному віці, або коли тяжко хворіли, проте траплялись випадки, коли передпоховальний період у горян тривав десятки років. Для старих гуцулів важливою $є$ завчасна передпоховальна підготовка, щоб у разі настання їхньої смерті, у родичів було менше проблем 3 похованням.

Традиційна обрядовість на Гуцульщині дуже тісно переплітається 3 християнством, хоч i збереглося чимало язичницьких обрядів. Ще 3 дитинства дітей вчать молитися Богу, додержуватись церковних постів та загалом ставитись шанобливо до християнських обрядів. Як тільки дитина досягає шести років, батьки вчать іï дотримуватись постів: у перший рік діти постять тільки тиждень, після чого батьки ведуть дітей до церкви причащатись; наступного року діти постять два тижні; а коли дитині виповнюється десять, то вона постить уже весь церковний піст. 
Дотримуватись церковних постів притаманно усім українцям, але на сьогодні тільки на Гуцульщині «тримати піст» залишається незмінно важливою формою в духовному житті гуцулів. Адже крім великих постів, гуцули також утримуються від «скоромних» видів їжі в понеділок, середу і п’ятницю. В перший день тижня постять за всіх святих, щоб ті берегли їх сім'ю та худобу, у середу - за Пречисту Діву Марію, щоб вона прощала їх гріхи, а в п’ятницю - в знак мученицької страти Ісуса Христа, щоб Господь милостивим був до них на «тому» світі (с. Стебні). « Гуцули вірять, що ті хто перейшов у інший, кращий світ, проводять час у молитвах перед Богом за нині живучих та ненароджених» [10, 52].

Для гуцулів важливою було і залишається натуральність всіх речей, які використовуються в ритуальних поховальних діях. Ритуальна свічка, яка буде горіти у руках небіжчика, обов'язково повинна бути виготовлена натурального власноруч своїм господарем 3 натурального воску та сплетена із трьох тонких в одну. ЇЇ заборонено використовувати в інших цілях, окрім як запалювати у руках власника, коли той буде помирати (с. Шепіт). Важливо, щоб в мить смерті при покійнику була запалена свічка, бо, умираючи без світла, в світі мертвих він блукатиме у пітьмі до кінця часів [10, 51]. Важливим моментом у підготовці до потойбічного життя $є$ підбір труни, яку на Гуцульщині називають «домовина». Гуцули завчасно готують домовину для іншого світу і роблять її виключно із смереки, бо вважають, що це дерево є найбільш рідне для тіла, і недовго буде гнисти, на відміну від твердих порід дерев. Верх труни гуцули обпалюють паяльною лампою, щоб вона мала вигляд рельєфу серцевини дерева (с. Селятин). Труну для небіжчика виготовляли чужі люди, родичі не мали права приймати в цьому участі, бо вважалось, що вони таким чином пришвидшують відхід майбутнього господаря в «інший» світ $[7,156]$.

Серед обов'язкових поховальних приготувань на Гуцульщині важливе місце посідає поховальний одяг, який гуцули робили 3 натуральних тканин та хутра. Верхній одяг робився 3 вовняного хутра (кептар, жупан, чоловічий головний убір - кресаня, тощо). Нижній одяг виготовляли 3 конопляних, або лляних тканин (білі сорочки з вишивками і без, жіночі запаски, чоловічі брюки.) Взуття, пояс та торбинки виготовлялись зі шкіри. Жіночий комплект одягу обов'язково мав включати в себе такі елементи одягу: постоли, онучі, запаска, сорочка, кептар, дві хустки. У чоловічий комплект одягу входили: постоли або чоботи, гачі, довга сорочка переважно з конопель, широкий пояс (черес), жупан, головний убір, кресаня, капелюх (с. Сергії). Одяг міг включати певні зміни, це залежало від статусу померлої людини. До смерті готували новий святковий одяг. А подекуди для цього шили сорочку особливого крою та вишивки, яку живі ніколи не одягали, зауважує науковець Марія Маєрчик [9, 73, 74].

Ще одним важливим моментом у передпоховальній обрядовості буковинських гуцулів $є$ передача свого майна в спадок. Заповіт на Гуцульщині складає господар, дуже рідко господиня (у разі раптової смерті чоловіка). Найчастіше все нажите майно діставалось найменшій дитині, але траплялись і винятки, коли цінності заповідались комусь із старших дітей, якщо ті були більш прислужливими. Бездітні гуцули передавали своє майно у спадок тим, хто його дотримував до смерті (с. Стебні). Останній, передсмертний заповіт перед родиною стосувався суто поховання господаря. «Громадою села суворо регламентувалося виконання цього останнього в житті людини заповіту. Переважно це стосувалося того, як, де та біля кого поховати, які страви та напої подавати на поховальну трапезу, яким чином розпорядитися майном» тощо $[7,157]$.

У різних регіонах України існує своє бачення у виборі місця на кладовищі. Варто сказати, що термін «кладовище» притаманне східній частині України, на заході частіше кажуть «цвинтар», чи «гробки». Українці вибирають цей клаптик землі теж по-різному. На Бойківщині після смерті одного iз подружжя, сусідне місце на цвинтарі обгороджують для іншого. Для гуцулів дуже важливе значення має збереження місця на цвинтарі біля своїх кревних померлих. Вони стежать, щоб біля їх родини не поховали когось чужого, бо кожен член сім’ї вважає за честь, щоб в майбутньому, 3 відходом на «інший» світ «спочивати» біля своїх предків. Тому у деяких селах Гуцульщини збережені захоронення від сьомого покоління. Значимість цього моменту полягає не тільки в тому, щоб бути похороненим біля рідних, а й у тому, що він слугує історичною пам'яткою роду для нових поколінь.

Ключовим фактом є й те, що гуцули вважають за потрібне не ставити бетонних, чи металевих пам'ятників померлим родичам. Вони віддають перевагу дерев'яним хрестам, а 3 часом просто змінюють надписні таблички на ньому. Це бажання горян пов'язане з їх віруваннями, що коли настане страшний суд, то всі померлі повинні будуть іти до Бога зі своїм хрестом, а якщо він буде бетонний, чи металевий, його неможливо буде понести на Суд Божий (с. Усть-Путила). 
На Буковинській Гуцульщині хрести як поховальні знаки утвердились на могилах лише в XIX ст. $[7,156]$. Останньою передпоховальною обрядовістю на Буковинській Гуцульщині є проща. Коли гуцули відчувають, що скоро будуть помирати, вони кличуть тих, з ким ворогували або кому робили зло для того, щоб попросити пробачення та з чистою душею відійти на «той» світ. Бувають і випадки, що до тяжкохворого поспішають винуватці, щоб встигнути очистити перед ним свою совість. Також бувають випадки, що коли хтось із старих у селі хворіє, то до нього самі ідуть за прощенням ті, хто відчуває себе винним перед хворим, щоб встигнути вибачитись. Така традиція притаманна не тільки гуцулам, а й практично по всій Україні. Роман Гузій, проводячи польові дослідження в селах буковинської Гуцульщини наводить такі відомості: «Якщо хтось ни хоче простити- тай має він гріх. Каже Біблія, шо шо зв'язане на земни, буде зв'язано і в Отця Небесного, а шо розв'яжеш на земни, буде розіязано і в Отця Небесного» (с. Селятин Путильського р-ну), [4, 207].

Другим великим етапом у поховальній обрядовості гуцулів $\epsilon$ похорон. «Смерть уважалася за родовий акт, за повернення до батьків у «родове місце» $[11,240]$. Гуцули твердо вірили, що причина смерті в тому, що за ними приходить хтось із померлих родичів і забирає їх до себе [11, 240]. В давнину, а подекуди ще і сьогодні, про смерть на Гуцульщині сповіщають трембітанням сумної мелодії, опустивши трембіти донизу $[1,225]$.

Коли помирає гуцул, родичі чи ті, хто доглядав його, кладуть йому в руки ту саму ритуальну свічку, яку за життя приготував небіжчик. В кімнаті покійного закривають рушниками всі дзеркала $\mathrm{i}$ те, що якимось чином віддзеркалює. Все, що в кімнаті було їстівне, викидається, бо вважається мертвим (с. Стебні).

Якщо людина довго не могла померти, йому давали в руки свячену свічку, «щоб муки зцілити і душу з грішним тілом розлучити» $[13,144]$.

За давньою традицією, через дві години після того, як помер гуцул, родичі кличуть двох людей тієї ж статі, що і померлий, щоб ті помили покійника та переодягли в одяг приготовлений небіжчиком за життя. В цей же час хтось із родичів померлого сповіщає церковного паламаря, щоб той задзвонив у дзвони. Вдаряти у дзвони паламар повинен три рази в день: вранці, обід і ввечері, поки покійника не захоронять. Гуцули вірять, що поки не задзвонять церковні дзвони за відходом душі покійника, то душа та блукає глухими місцями, полями, лугами, тощо. А при звучанні дзвонів вона знаходить шлях за призначенням $[6,168]$. Воду, в якій мили небіжчика, важливо вилити в таке місце на території господарства, щоб на неї ніхто з живих не ступав, а з тварин не пив, бо то - мертва вода. Всі родичі померлого мають носити той одяг, в якому були одягнуті на момент смерті рідного, доки тіло покійника буде знаходитись в хаті. Чоловіки в родині небіжчика не голяться сорок днів після смерті родича, а жінки носять чорну хустину цілий рік. Якщо родич помирає не своєю смертю, а скоює самогубство, то не проводять жодної поховальної обрядовості, таку людину хоронять в кінці цвинтаря, відведеного для таких випадків (с. Стебні).

На Гуцульщині існує повір'я, що, коли хтось помре у перший тиждень після Великодня, то він одразу відправляється до Царства Божого, бо цього тижня брама до раю відкрита (с. УстьПутила). Протягом усіх днів, доки тіло померлого знаходиться в будинку, туди ідуть всі бажаючі на останне прощання. Люди приходять із свічкою, запалюють іï, моляться і після цього вітаються 3 усіма, промовляючи «здорові будьте», таким чином бажають здоров’я родині покійника $[1,225]$. Для порівняння, на східній Україні з родиною небіжчика раніше віталися «слава Богу».

Під час прощальних відвідувань небіжчика, в кімнаті покійника завжди знаходиться хтось із рідних, який стежить, щоб ніхто із чужих не взяв нічого із тіла померлого, бо гуцули вірять, що це може принести нещастя в родину (с. Дихтинець).

В кімнаті, де лежить тіло покійника, заборонялось палити грубку, голосно розмовляти, їсти, спати. В день, коли тіло виносили 3 хати до церкви і на цвинтар, священник кликав усіх родичів в кімнату, де лежало тіло, щоб ті присіли на лавки, з яких забрали труну їх кревного, щоб родина трималась дружно та щоб жили і надалі в цій хаті, а рід не переводився (с. Стебні).

У давнину на Гуцульщині існував звичай: коли померлого виносили 3 хати надвір, в кімнату, де лежав покійник, заходила поважна в селі жінка, яка закривали вікна i двері, а після цього брала приготовлений господарями горщик і розбивала його об землю. Робилось це для того, щоб всі біди закінчились у цій хаті для родини $[6,171]$.

Досить поширеним на Гуцульщині було і залишається нині, голосіння родини за померлими родичами. Зазвичай, голосять тільки представниці жіночої статі, але бувають і випадки, де голосять чоловіки. Голосіння - це досить важливий елемент в поховальній обрядовості, що символізує жаль за вічною втратою своєї рідної людини. За легендою, перше голосіння було виконане, ще коли померла перша людина на землі, Адам. Воно було настільки жалісним, що Бог просив померлого Адама 
встати, але Адам, запитав у Господа, чи потрібно буде йому помирати вдруге, якщо він встане, Бог відповів, що потрібно, тоді Адам відмовився вставати $[8,128]$.

Гуцули голосили переважно в хаті померлого, а в деяких місцевостях Гуцульщини заборонялось це робити взагалі, щоб не заважати покійнику спокійно відійти в світ мертвих $[12,99]$.

Прийшовши на цвинтар, родичі влаштовували родовий акт - обрядову зустріч новоприбулого мерця 3 померлими раніше родичами. Плакальниці звертались до предків, щоб ті вийшли назустріч до мерця, прийняти його до свого гурту та надалі опікувалися ним на «тому» світі $[11,204]$.

Багато традиційної поховальної обрядовості на Гуцульщині пов'язано з водою та вогнем, які для гуцулів мають цілющі властивості протягом усього календарного року. На Гуцульщині в день поховання, родичі покійника кличуть усіх людей, котрі супроводжували поховальну церемонію, прийти 3 цвинтаря на комашню. У дворі, де жив покійник, родичі ставлять відро з водою і рушник, щоб кожен прихожий на поминки, перш ніж сісти за стіл, мав злити тією водою тричі на руки. Відро з водою і рушником мало залишатись у дворі цілу ніч, щоб покійні душі родичів змогли собі теж помити руки $[13,148]$.

«На перші три дні по смерті на вікні чи на столі ставиться посудинка 3 водою, щоб душа могла собі легко обмиватися, а то й пити, і навіть видно, як вода в посудині помалу убуває» $[5,239]$.

«Переважна частина обрядодій, які здійснювалися у похоронному обряді, мали на меті якнайшвидше переправлення душі померлого у потойбічний світ - світ предків, світ мертвих» [7, 163].

Третім етапом у поховальній обрядовості на Буковинській Гуцульщині є вшанування культу предків. Ще 3 дитинства гуцулів вчать вшановувати своїх предків. Горяни вірять, що задобрені предки допомагають своїм живим нащадкам в побуті, слугують своєрідним оберегом у родині, впливають на врожаї городини, саду, розплід худоби, птиці, тощо (с. Стебні).

У давнину вірили, що з приходом весни, коли оживає вся природа, покійники виходять на цей світ. Щоб задобрити небіжчиків, дівчата й молодиці виводили гаївки, які проходили «на гробках», хлопці теж вели свої ігри поруч жіноцтва, щоб тим самим догодити небіжчикам чоловічої статі [3, 185-186].

Вірування гуцулів у постійний зв'язок між мертвими і живими в основній мірі і сформувало обрядові дії з культом предків у поминальні дні, які на Гуцульщині твердо дотримуються і посьогодні: на Різдво Христове закликанням предків до Святої вечері, на Великдень - поманою біля церкви, на Дідові суботи - поманою на цвинтарі. На Гуцульщині існує повір'я, що колись, дуже давно, померлі діди випросили у Бога три поминальні дні, коли можна молитися за душі померлих, а померлим за живих $[11,240]$.

Традиційно предків вшановували в кожну пору року. Зимові вшанування предків припадали на другий тиждень перед великим постом, весняні - на Великдень, або першу суботу після Пасхи, літні - перед Зеленими святами, осінні - в останню суботу перед пилипівськими запусками $[7,165]$.

Горяни і нині твердо вірять, що милосердя в пам'ять померлих дають рясні плоди і допомагають душам покійників позбутися своїх гріхи. В основу милосердя гуцули ставлять три опори: молитву, літургію, милостиню [2, 133].

Висновки. Дослідження довело, що в поховальній обрядовості на Буковинській Гуцульщині $є$ усталена предками послідовність дій, які передається 3 покоління в покоління. Від належного дотримання предкових поховальних обрядів залежить добробут всієї родини, їх господарства. Не менше значення, ніж дотримання поховальних дій, мають обрядові дії, пов'язані із вшануванням культу предків, вони несуть в собі велике духовне навантаження для українців Буковини. Гуцули вірять, що їх померлі родичі впливають на перебіг подій в родині, вони можуть як допомагати своїм рідним, так і робити їм погані вчинки. Саме «предки», на думку буковинських гуцулів, забирають їх до себе, після смерті. Вони є посередниками, між живим світом і світом мертвих.

\section{Jimepamypa}

1. Борисенко В. Сімейна обрядовість українців XX-початку XXI століття. К.: ІМФЕ, 2016. 256 с.

2. Ватаманюк К. Між хрестами і зорями. Чернівці- Верховина: «Друк Арт», 2014. 238 с.

3. Воропай О. Звичаї нашого народу: етнографічний нарис. Х.: «Фоліо», 2013. 508 с.

4. Гузій Р. 3 народної танатології: карпатознавчі розсліди. Л.: Ін-т народознавства НАНУ, 2007. 352 с.

5. Дохристиянські вірування українського народу: Історичне релігієзнавство, монографія. К.: АТ «Обереги», 1994. 424 с.

6. Кайндль Р. «Гуцули»: їх життя, звичаї та народні перекази. Чернівці: «Молодий буковинець», 2000.

$208 \mathrm{c}$.

7. Кожолянко Г. Духовна культура українців Буковини. Чернівці: «Прут», 2007. 403 с. 
8. Коваль-Фучило І. Українські голосіння: антропологія традиції, поетика тексту. К.: НАН, IМФЕ ім. М.Т Рильського, 2014. 360 с.

9. Маєрчик М. Ритуал і тіло: структурно-семантичний аналіз українських обрядів родинного циклу. К.: «Критика», 2011. 324 с.

10. Мусіхіна Л. Магія гір. Чарівне в житті гуцулів. Тернопіль: «Богдан», 2012. 64 с.

11. Сеньків І. «Гуцульська спадщина». Праці з життя і творчості гуцулів. Чернівці-Верховина: «ДрукАрт», 2014. 512 c.

12. Чумарна М. Тройдерево: обряд хрещення, весільний та поховальний обряди українців: навч. кн. Тернопіль: «Богдан», 2013. 102 с.

13. Чорі Ю. Від роду до роду. Звичаєво-обрядові традиції Закарпаття. Ужгород: «В Подяка», 2001.168 с.

\section{References}

1. Borysenko V.K. (2016). Family ritual of Ukrainians of the XX - beginning of the XXI century. Kyiv: National Academy of Sciences of Ukraine, IMF [in Ukrainian].

2. Vatamaniuk K.M. (2014). Between crosses and stars. Chernivtsi: Verkhovyna: Print Art [in Ukrainian].

3. Voropai O. (2013). The customs of our people. Kharkiv: Folio [in Ukrainian].

4. Guzii R. (2007). From folk andanatology: Carpathian investigations. Lviv: Institute of Ethnology of the National Academy of Sciences of Ukraine [in Ukrainian].

[in Ukrainian].

5. Hilarion, Metropolitan. (1994). Kyiv: Pre-Christian beliefs of the Ukrainian people. Kyiv: AT «Amulets» Ukrainian].

6. Kaindl R.F. (2000). "Hutsuly": their life, customs and folk legends. Chernivtsi: Young bucovynets [in

7. Kozholianko G. K. (2007). Spiritual culture of Ukrainians of Bukovyna. Chernivtsi: Prut [in Ukrainian].

8. Koval-Fuchylo I. (2014). Ukrainian lamentations: an anthropology of tradition, poetics of the text. Kyiv: NAS, IMF them. MT Rylsky [in Ukrainian].

9. Maierchyk M. (2011). Ritual and body. Kyiv: Critics [in Ukrainian]. Ukrainian].

10. Musikhina L. (2012). The magic of the mountains. Charming in the life of Hutsuls. Ternopil: Bohdan [in

11. Seniuk I. (2014). "Hutsul Heritage". Works on the life and work of Hutsuls. Chernivtsi: Verkhovyna: Print Art [in Ukrainian].

12. Chumarna M. (2013). Troyderevo: the baptismal ceremony, the wedding and burial ceremonies of Ukrainians. Ternopil: Bohdan [in Ukrainian].

13. Chori Yu. (2001). From generation to generation. The custom-ritual traditions of Transcarpathia. Uzhhorod: Gratitude [in Ukrainian].

Стаття надійшла до редакиії 11.12.2018 p. 